\title{
Toimijalähtöinen prosessikehittäjä sosiaali- ja terveydenhuollossa
}

Riitta Seppänen-Järvelä

\begin{abstract}
Kiinnostus työorganisaatioiden kehittämiseen on vahvaa, niin myös sosiaali- ja terveydenhuollossa.

Kirjoittaja haastatteli kolmessa suuressa

kehittämisprojektissa työskennellyttä henkilöä

väitöskirjatutkimustaan varten. Sen tuloksena jäsentyi

toimijalähtöisen prosessi-kehittäjän ote työtä ohjaavana ajattelutapana. Mitä tämä työnote merkitsee ja millaisia ovat kehittäjän erilaiset roolit?
\end{abstract}

Kehittäminen on ollut organisaatioiden iskusana viimeiset kaksi vuosikymmentä. Siitä on tullut vahva voima sosiaali- ja terveydenhuollon hallintoon ja palveluihin. Jatkuvaa muutosta ja oppivaa organisaatiota korostavat trendit pitävät kehittämistä ja innovatiivisuutta menestyksen avaintekijöinä. Kehittämisprojektit on omaksuttu osaksi työkäytäntöjä; kehittämisslangi innovaatioineen ja visioineen on tuttua.

Valtionhallinnon muuttuneet ohjaustavat, siirtyminen pois keskitetystä normiohjauksesta, antoivat luvan ja toisaalta pakottivat kehittämispyrkimyksiin. Myös hallinnon reformit ja niissä omaksutut organisaatioita ja niiden toimintaa koskevat ajattelutavat ovat kehittämistyön vahvistumisen taustalla. Läntisissä teollisuusmaissa toteutetut julkisen hallinnon uudistukset 1980 1990-luvuilla yhdistetään tavallisesti New Public Management -suuntaukseen (NPM) (Temmes 1998; Naschold 1995). Toisaalta ne voidaan kytkeä monisyisiin muutosvoimiin ja asettaa osaksi pidempää prosessia, jota Ahonen (1997) kuvaa hallinnon muodonmuutoksena.

Työn, politiikan ja kulttuurin yhteenkietoutumista kuvataan globaalitalouden ilmiönä. Puhutaan informationismin ajasta, jossa korostuu niin yksilöiden kuin organisaatioiden kyky luoda ja hyödyntää tietoa. (Castells 1996.) Työ muuttuu yhä enemmän tietotyöksi, tiedon asiantuntijuudeksi. Asiantuntijoiden kuvataan työskentelevän tietointensiivisissä organisaatioissa. Kehittämisen asiantuntijat ovatkin eräs tietoon nojaavan kulttuurin ilmentymä. Asiantuntijuuden luonne on kuitenkin monissa suhteissa muuttunut; toisaalta puhutaan asiantuntijuuden rapautumisesta, toisaalta taas uhkana nähdään asiantuntijoiden dominoima yhteiskunta, ekspertokratia (ks. Eräsaari 1996; Kasvio ym. 1999). Kehittämistoiminnan vahvistumisen myötä myös kehittäjien ajattelu- ja toimintatavoilla on merkitystä. Muutok- 
sen airueina he kuljettavat uusia ajatteluvirtauksia, organisoivat, verkostoivat ja katalysoivat (Valkeavaara 1997; Filander 1995). He ovat itse olennainen osa työnsä ilmiötä; he sijaitsevat ilmiön sisällä, realisoivat ja rakentavat sitä.

Kiinnostus työorganisaatioiden kehittämiseen on vahva. Jatkuvaa muutosta ja oppivaa organisaatiota korostavat trendit ovat lisäämässä motivaatiota kehittämistä kohtaan. Lähestymistapojen muuttuminen vuorovaikutteisempaan, verkostomaiseen, ylhäältä alas -suuntaan liittyvät nekin laajempaan asiantuntijaroolien murrokseen. Kehittäminen ja tiedon välittäminen on myös omaksuttu deregulaation ajan hallintojärjestelmien välineeksi ohjata toimintoja, kuten sosiaali- ja terveyspalveluita. Tästä funktiosta katsottuna onkin kiinnostavaa, millaisena keskushallinnossa työskentelevät kehittäjät työnsä hahmottavat.

$\mathrm{T}$ arkastelen tässä artikkelissa väitöstutkimukseni (Seppänen-Järvelä, 1999) aineistoon perustuen kehittämistyön tiettyjä erityispiirteitä kehittämisen ammattilaisten näkökulmasta kontekstina sosiaali- ja terveydenhuollon valtakunnalliset kehittämishankkeet. Esittelen lyhyesti empiirisen aineiston analyysiin perustuvan toimijalähtöisen prosessikehittämisen otteen ja keskustelen tarkemmin kehittäjän roolin luonteesta ja moninaisuudesta.

\section{Tutkimuksen asetelma ja aineistot}

$\mathrm{T}$ utkimuksen taustalla olivat havainnot, että kehittämistyö tarvitsee - omana alueenaan - täsmällistä tarkastelua. Kehittämisen tahto ja tavoitteet ovat olleet hyvin esillä mutta sisällöstä tai menetelmistä ei ole keskusteltu paljoakaan. Tutkimukseen onkin kaivattu sellaista analyysiä, joka selvittäisi sitä, millaiseen muutosajatteluun kehittämistyön toteuttaminen perustuu (Rajavaara 1994, 56). Myös Edgar Schein $(1999,4)$ on havainnut, etteivät kehittäjät ja konsultit tiedosta, millaisiin oletuksiin heidän toimintansa nojaa.

Kysyin tutkimuksessani, millaisena kehittämistoiminnan ymmärtävät sitä toteuttavat ihmiset. Ajatuksena oli antaa kehittämistyön asiantunti-

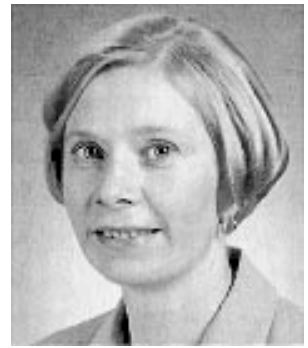

Riitta Seppänen-Järvelä

jalle "ääni”. Asiantuntijoiden kokemusten ja oman toiminnan reflektion kautta hahmotettiin kuvaa tutkimuskohteen ominaisuuksista ja piirteistä. Tutkimuksen tavoitteena oli näin kuvata, millaisten oletusten varassa asiantuntijat toimivat.

Tutkimuksen aineisto koostui Stakesin toteuttaman kolmessa suuressa kehittämisprojektissa työskentelevien henkilöiden ( $\mathrm{N}=13)$ haastatteluista. Projektit olivat Perhesuunnittelu 2000, Palvelurakenteen ympäristöt ja Mieli Maasta - Valtakunnallinen depressioprojekti. Projektien yhteistyökumppanit olivat pääasiassa kuntien henkilöstöä. Haastatteluaineisto analysoitiin grounded theoryn (Strauss \& Corbin 1990) mukaisesti Atlas/ti-analyysiohjelmalla (http:// www.atlasti.de). Toimijalähtöisen prosessikehittämisen ote projekteja ohjaavana ajattelutapana jäsentyi aineiston analyysin edetessä. Vastaavantyyppistä ajattelu- tai lähestymistapaa ei ole aiemmin esitetty, vaikka yhteisiä piirteitä muihin kehittämisen suuntauksiin oli havaittavissa.

Stakesia ei valittu sattumalta sosiaali- ja terveydenhuollon kehittämistyön ilmentäjäksi ja tutkimuskohteeksi. Organisaatio on keskeinen toimija sosiaali- ja terveydenhuollon kentässä. Sen tehtäväksi on kuvattu sosiaali- ja terveydenhuollon informaatio-ohjaus, edeltäjäorganisaatioidensa valtiokeskeisen normiohjauksen sijaan (Uusitalo \& Lönnfors 1999). Stakesin asemasta kertoo myös organisaation koko: sen palveluksessa oli vuonna 1998 yhteensä 407 henkilöä ja rahoitus mukaan lukien valtion budjettirahoitus, maksullinen toiminta ja muu hankerahoitus oli yhteensä 172,6 milj.mk (Stakes 1999). Va- 
litsin Stakesin tutkimusympäristöksi sen organisaatiohistorian ja position vuoksi. Organisaation aiempi asema hallintoviranomaisena ja nykyinen tehtävä informaatio-ohjaajana asettaa sen harjoittaman kehittämistoiminnan kiinnostavaan valoon.

Empiiristä aineistoa ei tarkasteltu projekti- tai yksilökohtaisesti, vaan haastateltavien käsitykset muodostavat käsitysten kokonaisuuden (pool of meanings) (Marton 1988). Projektien kautta informanttien kokemukset ja näkemykset kiinnittyivät konkreettiseen kehittämistyön kontekstiin. Kun tutkimustehtävään tartuttiin työntekijöiden kokemuksiin ja ajatteluun perustuvilla käsityksillä, ei siinä voida ottaa kantaa siihen, toimivatko henkilöt projekteissaan kuvaamallaan tavalla tai kuinka osuvia käytetyt menetelmät ovat olleet kyseiselle kohdealueelle.

\section{Toimijalähtöinen prosessikehittäminen}

Seuraavassa tarkastelen empiirisen aineiston perusteella muodostamaani kehittämisotetta, toimijalähtöistä prosessikehittämistä. Se on haastateltavien näkemyksiin perustuva käsitteellinen konstruktio, kehittämistyön toteuttamista kuvaava ajattelu- tai lähestymistapa.

Puheaineiston luonne huomioon ottaen ei voida sanoa, että kehittämisote kuvaisi kehittämistyön toiminnan toteuttamista. Aineiston asema on ennemminkin kertoa tutkimustehtävän mukaisesti kehittämistyön luonteesta, sen ominaispiirteistä.

$\mathrm{T}$ oimijalähtöisissä projekteissa tavoitteena oli tukea ja edistää paikallisia kehittämispyrkimyksiä valtakunnallisten projektien kehyksissä. Valtakunnalliseen hankkeeseen kiinnittyi laaja variaatio rakenteeltaan ja sisällöltään erilaisia tehtäviä. Valtakunnallinen projekti antoi siis tietyn suhteellisen löyhän tavoitteellisesti suuntaavan viitekehyksen, jonka sisälle sijoitettiin paikallisia projekteja. Tämäntyyppinen ohjelmien kokonaisrakenne näyttäisi olevan melko tavallinen deregulaation ajalle (esim. Albæk 1995; Ekholm 1994).
$\mathrm{K}$ ehittämistyön toimintatavat ovat muuttuneet noin kymmenen viime vuoden aikana selvästi. Taustalla on monia tekijöitä, jotka ovat yhteydessä laajempiin työelämää ja organisaatioita koskeviin muutosajatteluihin, kuten New Public Management -ajatteluun tai oppivaan organisaatioon. Toimijalähtöinen toimintatapa on vastaus keskushallinnon kehittämistyön muutospaineisiin ja globaaleihin kehittämistrendeihin. Muutos keskushallintokeskeisestä suunnittelu- ja kehittämistyöstä toimijoiden tarpeisiin reagoivaan kehittämiseen on ollut kulku, joka on yhteydessä myös laajempaan muutosajatteluun, esimerkiksi johtamisen (Daudelin 1996), kehitysyhteistyön (Oakley 1990), opettamisen ja kouluttamisen (Rauste-von Wright \& von Wright 1996) sekä tutkimuksen alueilla (toimintatutkimuksen osalta ks. Kasvio 1994). Tämäntyyppistä ajattelutapaa nimitetään näkökulman ja keskusteluyhteyden mukaan hieman eri tavoin. Se voi olla esimerkiksi asiakas-, potilas- tai oppilaskeskeisyyttä. Nimitän haastateltavien omaksumaa toimintatapaa toimijalähtöiseksi.

Prosessikehittämiselle oli ominaista avoimuus
ja eteneminen kulloisenkin tilanteen ehdoin. Sille oli tyypillistä ennakoimaton vaiheittaisuus, joka poikkesi perinteisestä rajatusta ja kontrolloidusta kehittämistehtävästä. Toimijakenttää ja etenemisen vaiheita ei oltu hankkeen alkuvaiheessa rajattu, vaan ne hahmottuivat prosessin interventioiden edetessä. Projektisuunnitelma määritti lähinnä tavoitteet ja vaikutussuunnan, jotka antoivat väljän kehyksen kehittämistehtävän toteutukselle. Tehtävä tarkentui prosessin aikana syntyvien tilanteiden mukaisesti. Prosessin etenemistapa oli rönsyilevä, mutta voimakas tavoitetietoisuus, arviointi ja vaikutussuunnan selkeys olivat keinoja pitää avoin prosessi raiteillaan. Taulukossa 1 on tiivistetty toimijalähtöisen prosessikehittämisen keskeiset ominaisuudet.

\section{Kehittäjä prosessin kuljettajana}

Aineistossa esille tullut kehittämisote, toimijalähtöinen prosessikehittäminen heijastui haas- 
tateltavien näkemyksissä, jotka koskivat omaa asiantuntijuutta, osaamista tai rooleja. Kehittäjän asiantuntemus ja ammattitaito liittyivät keskeisesti kehittämisen prosessin käynnistämiseen, kuljettamiseen ja ylläpitämiseen. Siinä tarvittiin tietoa ja taitoa havaita, ymmärtää ja käsitellä prosessimaista tilannedynamiikkaa. Vuorovaikutustaidot, kuten kyky kuunnella ja reflektoida, olivat tärkeitä. Asiantuntemusta voidaan luonnehtia reflektiiviseksi tai hiljaiseksi taitotiedoksi, joka näyttäytyy paljolti intuitioon perustuvissa rat-

\section{Taulukko 1.}

Toimijalähtöisen prosessikehittämisen piirteet

1 Toteutusstrategia tilanne-ehtoinen ja avoin kontekstuaalisille tekijöille

1 ei tarkkaa toteuttamista ohjaavaa tai rajaavaa suunnitelmaa

1 prosessin etenemistä ohjaa tietoisuus vai kutussuunnasta

1 prosessi hidas, muuntuva, aikaan sidottuja muodoltaan rönsyilevä

1 kehittämistehtävä muotoutuu prosessin aikana

1 ennakoimattomuus, epävarmuus ja riskit prosessin etenemisessä

1 toimintatapa perustuu yhteistoiminnalliselle dialogisuudelle

kaisuissa. Se on tekemisen taitoa ja osaamisen vaistoa. Eräs haastateltavista formuloikin tämän osaamisen prosessiasiantuntijuudeksi. Timo Keski-Petäjä käyttää käsitettä prosessirohkeus, jolla hän tarkoittaa projektiin heittäytymistä ilman tiukkaa toteuttamista ohjaavaa suunnitelmaa. Rohkeudella viitataan kykyyn ottaa vastaa ennakoimattoman prosessin tuomia tilanteita ja käänteitä. Näin projektin etenemisen annetaan muotoutua omaehtoisesti. (Keski-Petäjä 1999.)

$\mathrm{P}$ rosessiorientoituneen kehittämistyön toteuttamisen lähtökohta oli prosessin kuljettaminen ja ohjaaminen. Olen valinnut tietoisesti verbin kuljettaa. Tällöin ei puhuta vain ohjaamisesta tai toteuttamisesta vaan kuljettaminen henkii tukevan saattajan aktiivista otetta. Kuljettamiseen liittyi ohjaamista mutta siihen liittyi myös yhteistyösuhde kuljetettavien kanssa. Tavoitteelli- sen projektitehtävän toteuttaminen vaati näin ohjaamista ja johtamista vuorovaikutukseen ja yhteistyöhön perustuvassa toimijalähtöisyydessä. Kuljettamiseen kuului se, että Stakesin edustaja vahvisti ja edesauttoi projektikumppaneita kehittämispyrkimyksessä. Prosessin luonne ja piirteet, kuten ennakoimaton vaiheittaisuus, loivat pohjan kehittäjän toiminnalle prosessin kuljettamisessa. Tietty tapahtuma prosessissa johti johonkin seuraavaan ja vaikutti tulevaan. Tämäntyyppisenä askel askeleelta etenevänä polkuna on kuvattu myös toimintatutkimuksellisten työelämän kehittämishankkeiden toteuttamista $(\mathrm{mm}$. Buhanist ym. 1994, 92).

Prosessiasiantuntijuuden ydin liittyi tilanneherkkyyteen: kykyyn oivaltaa nopeasti potentiaalinen hetki ja käyttää se prosessin etenemisen hyväksi. Tähän viittaa myös Kananoja (1981, 15) määritellessään kehittäjän henkilöksi, joka kykenee muuntamaan ajassa ja tilanteessa olevat mahdollisuudet käytännön toiminnaksi. Kehittäjän työssä oli tärkeätä kyky havaita ja käyttää - kuin shakkipelissä - prosessin myötä aukeavia tilanteita sekä ennakoida interventioiden vaikutuksia prosessin etenemiseen.

\section{Toimijalähtöisen prosessikehittäjän suhde substans si in}

Toimijalähtöinen prosessikehittäminen merroolista, vaikka sektoriasiantuntemuksen merkitys ei kuitenkaan hävinnyt. Kehitettävän teeman tuntemus ja ammatillinen asema substanssin sisällä toi uskottavuutta ja legitimoi työskentelyn. Kehittämistarpeiden rakentamisessa projekteiksi tarvittiin syvällistä sosiaali- ja terveydenhuollon tilanteiden ja muutoskulkujen sisällöllistä tuntemusta ja tunnistamista.

Toimijalähtöisen prosessikehittäjän roolin omaksuminen merkitsi sitä, että kehittäjä toimi marginaalisessa asemassa suhteessa kehitettävään toimintaan, substanssiin. Kehittäjä ikään kuin eriytyi kehittämisen, koulutuksen ja konsultaation maailmaan, josta käsin luotiin suhde kehitettä- 
vään toimintaan. Tällaista eriytymistä haastateltavat kuvasivat sillä, etteivät kehittämistyössä tarvittavan roolin oppiminen ja omaksuminen olleet itsestäänselvyyksiä. Haastateltavat kuvasivat tätä hieman eri tavoin sen mukaan, millaisesta taustasta he olivat kehittäjän rooliin lähteneet. Jotkut olivat siirtyneet kehittäjäksi tutkijan roolista, jollekin työ oli konsultatiivisen otteen opettelua. Yhteistä oli kuitenkin luopuminen jonkin alueen sisällöllisestä erityisasiantuntijuudesta, ratkaisujen antajasta tilanteiden luojan ja mahdollistajan asemaan. Henkilölle, jonka osaaminen oli perustunut oman alan erityiskysymysten sisällölliseen hallitsemiseen, tämäntyyppinen prosessi- ja toimijaorientoituneempi työskentelyote merkitsi luopumista.

Haastateltavien joukossa oli myös sellaisia henkilöitä, joille käynnistynyt projekti oli työalueena suhteellisen uusi, eivätkä he katsoneet olevansa kyseisen alan vahvoja asiantuntijoita. Uusi toiminta-alue merkitsi aluksi epävarmuutta, mutta työskentelemisen kautta karttui myös alueen sisällöllistä osaamista. Tämä liittyi myös siihen, että useat informantit painottivat projektista saamaansa oppimiskokemusta, uusi substanssialue toi tavallaan mukanaan asiantuntemuksen "aluevaltauksen”. Tämäntyyppistä oppimiskokemustaan kuvasi eräs haastateltavista, joka projektissaan oli ollut yhteistyössä monien erilaisten yhteistyötahojen kanssa. Kullekin organisaatiolle tai hallinnonalalle on tyypillistä sektorikohtaiset ominaisuudet, kulttuuriset piirteet ja puhetavat. Haastateltava kuvasi oppimiskokemustaan siten, että oli omaksunut eri projektikumppaneiden puhetavat ja pystyi uskottavasti vaihtamaan kieltä. Kieli kytkeytyy kulttuuriin ja on näin avain vuorovaikutukseen perustuvan kehittämistoiminnan toteuttamisessa (ks. Schein 1999, 103; Gustavsen 1992).

Stakesissa työskentelevät kehittäjät olivat taustaltaan substanssiasiantuntijoita eli heillä oli omaan koulutukseensa ja sektoriasiantuntemukseensa perustuva osaamisalueensa, esimerkiksi mielenterveystyö. Heidät oli rekrytoitu tietyn substanssialueen (ainealueen) osaajina. Ehkä osin tästä leimallisuudesta johtuen haastateltavat toivat esille erityistä kehittäjän osaamista. Kehittäjällä yh- distyivät kehittäjäosaaminen tai prosessiasiantuntijuus sekä substanssiosaaminen. Kehittäjällä onkin oltava laaja-alainen asiantuntemus; pelkkä substanssiosaaminen ei riitä (Jalava \& Virtanen 1998, 105). Voidaan kuitenkin sanoa, että ainealueen hallinnalla oli edelleen tärkeä merkitys. Tämä tuli esille myös kehittäjälle uuden ainealueen "haltuunottamisessa".

Substanssiasiantuntemus oli edellytys kontekstin hahmottamisessa ja uskottavuuden saavuttamisessa toimijoiden parissa. Se takasi tietyn legitimiteetin, joka vaikutti olevan välttämätöntä erityisesti terveydenhuollossa, jossa tarkasti säännellyillä ammatillisilla pätevyyksillä on suuri merkitys.

\ysymys uskottavuudesta ja luotettavuudesta kehittämis- ja konsultointitilanteissa on kiinnostava. Vaikuttaa siltä, että siihen kytkeytyy monia osaamisen ja pätevyyden elementtejä, vaikka tämän aineiston perusteella on vaikeata tarkasti sanoa, miten ja millaisia keinoja kehittäjät tietoisesti tai tiedostamattaan käyttivät uskottavuuden luomiseksi tai asemansa legitimoimiseksi.

\section{Kehittäjän moninaiset roolit}

$\mathrm{K}_{\mathrm{s}}$ ehittäjän roolia on kuvattu ristiriitaiseksi (Jaava \& Virtanen 1998, 144; Lindström 1997, 260; Filander 1995, 96). Esimerkiksi Paul Buhanist ym. $(1994,98)$ ovat havainneet, että toimintatutkijan rooli työelämän kehittämishankkeissa on huomattavasti moninaisempi kuin alan kirjallisuus antaa olettaa. Kuulan (2000) tutkimus, joka analysoi toimintatutkijoiden työtä retoriikkateorian valossa, tuo vahvasti esille työtapoihin, rooleihin ja niihin liittyvien odotusten ja mielikuvien ristivedon kehittämishankkeissa työskenneltäessä.

Kehittämistoiminnan toteuttamismuotojen sisällä on laaja jatkumo tutkivasta tai tutkimusavusteisesta kehittämisestä käytännölliseen "ei -akateemiseen" kehittämistyöhön. Tämä jo osin kuvaa kehittämisen intressejä ja toimintatapoja. Onkin luontevaa ajatella, että kehittäjän rooli on hieman erilainen erilaisessa suuntauksessa. Saman- 
tyyppinen tilanne on havaittavissa evaluaatiossa, jossa erilaiset roolit, kuten tutkija, tarkastaja, konsultti tai neuvottelija, viittaavat erilaisiin evaluaatio-otteisiin (Patton 1997, 122, 128129).

\section{$\mathrm{P}$} ohtiessaan konsultin rooleja Schein liittää tietynlaisen roolin tietynlaiseen konsultointimalliin. Asiakas saattaa hakea konsultin asiantuntemusta määrittelemäänsä ongelmaan, jolloin konsultti tulee ikään kuin täyttämään jonkin tietotarpeen. Lääkäri-potilastyyppinen konsultointisuhde viittaa siihen, että konsultti diagnosoituaan ongelman suosittelee ratkaisua sen selvittämiseen. Lisäksi Schein esittää prosessikonsultin roolin, jossa ongelma ja sen ratkaisu työstetään konsultin ja asiakkaan yhteisessä vuorovaikutuksellisessa prosessissa. Sillä, millaisen roolin kehittäjä tai konsultti kulloinkin valitsee, on tärkeä merkitys siihen, millaiseksi ja kuinka hyödylliseksi kehittämistilanne muodostuu. (Schein 1987, 1999.) Millainen rooli on sitten toimijalähtöisen prosessikehittämisen mukaan työskentelevällä kehittäjällä?

Toimijalähtöisen prosessikehittäjän roolien taustalla on keskushallinnon edustajan muuttunut asiantuntija-aseman ja tarve hahmotella "uudenlaista" kehittäjän hahmoa ja paikkaa. Honkasen mukaan muutokset toimintatavoissa ja rooleissa eivät ole ilmiöinä erillisiä vaan samantyyppinen dialogiseen suhteeseen perustuva ajattelutapa on huomattavissa esimerkiksi johtajan roolin muuttumisessa. Hän tähdentääkin, että siirtyminen asiantuntijan roolista avittajan rooliin on suurempi harppaus, kuin usein ymmärretään. Näissä kahdessa roolissa työskentely edellyttää aivan erilaista toimintaotetta, ammatillista asennetta, osaamista ja työmenetelmiä. (Honkanen 1999, 20.)

\section{$\mathrm{K}$} ehittämisotteena käytetty prosessikehittäminen ja toimijaorientoitunut toimintatapa valoivat perustan roolien kirjolle. Rooleja kuvaavat käsitysluokat nousivat aineistosta melko kirkkaasti, mikä osin ainakin kertoo siitä, että haastateltavien käsitykset roolien sisällöistä olivat suhteellisen yhtenevät. Roolit ovat luonteeltaan rinnakkaisia ja vaihtuvia, ja kirjo näyttää kehittäjän työotteen eri puolet. Informanttien kuvauksista kävi ilmi, että liikkuessaan kehittämistilanteiden moninaisuudessa he käyttivät ja vaihtoivat roolia tilanteiden mukaisesti. Tilanne-ehtoisessa, monitasoisessa ja -ulotteisessa kehittämistyössä roolien käyttäminen ja vaihtaminen oli keskeistä kehittäjän osaamista. Käytetyt roolit eivät olleet sattumanvaraisia, vaan niillä oli tietty kehittämistyön luonnetta kuvaava perusta. Voidaan siis sanoa, että kehittäjillä oli käytössä toimijalähtöiseen prosessikehittämisen viitekehykseen sopiva roolipaletti. Tilannetta voidaan kuvata viuhkalla, jonka tyvi muodostaa roolien perustan ja siipi vaihtuvien roolien kirjon (ks. kuva 1).

Useiden haastateltavien puheissa hieman eri muodoissaan näyttäytynyt kiinnostava teema oli kehittämistyön ymmärtäminen "ihmistyönä". Tämäntyyppinen käsitys kehittämisestä suuntaa myös kehittäjän roolia ja tuo esille vuorovaikutukseen perustuvaa toimintatapaa. Haastateltavilla oli näkemys, jonka mukaan kehittämistyössä tarvitaan kehittäjäominaisuuksia: tulisi olla "kehittäjätyyppi”. Tärkein näistä ominaisuuksista oli toimintaan orientoituminen, halu vaikuttaa ja viedä asioita eteenpäin. Tämä näyttäisi liittyvän henkilön laajempaan työtä ja toimintatapoja koskevaan orientaatioon. Myös Filanderin (1995, 101) tutkimuksessa kehittäjät kokivat itselleen välttämättömäksi eräänlaisen palavasieluisen sitoutumisen kehittämistehtävään. Voimakasta tehtävään sitoutumista pidetään myös yhtenä olennaisimmista asiantuntijatyöhön liittyvistä piirteistä (Kasvio 1994, 66).

$\mathrm{R}$ oolin lähtökohtana oli oma sitoutuminen ja nnostus asiaan; siinä on kuultavissa missiotyyppinen suuntautuminen. Voidaankin sanoa, että kehittämistyö liittyi melko vahvasti haastateltavien omaan kehittämismyönteiseen työorientaatioon: heille kehittäjyys oli osa elämäntapaa (myös Brännberg 1996). Saaren (1998) tapaan heitä voisi luonnehtia "sosiaalipoliittisiksi yrittäjiksi" eli henkilöiksi, joilla on kykyä seuloa ideoita ja toteuttaa niitä. Myös Kananoja pohtii kehittäjähenkilön piirteitä ja sanoo, että kehittäjän kuvaan sisältyy yleensä innovaatioita ja pioneerihenkeä. Kehittäjän tulee olla kiinnostunut sekä tavoitteista että keinoista, jolla hän 
Kuva 1. Kehittäjän työn vaihtuvat roolit ja niiden perusta

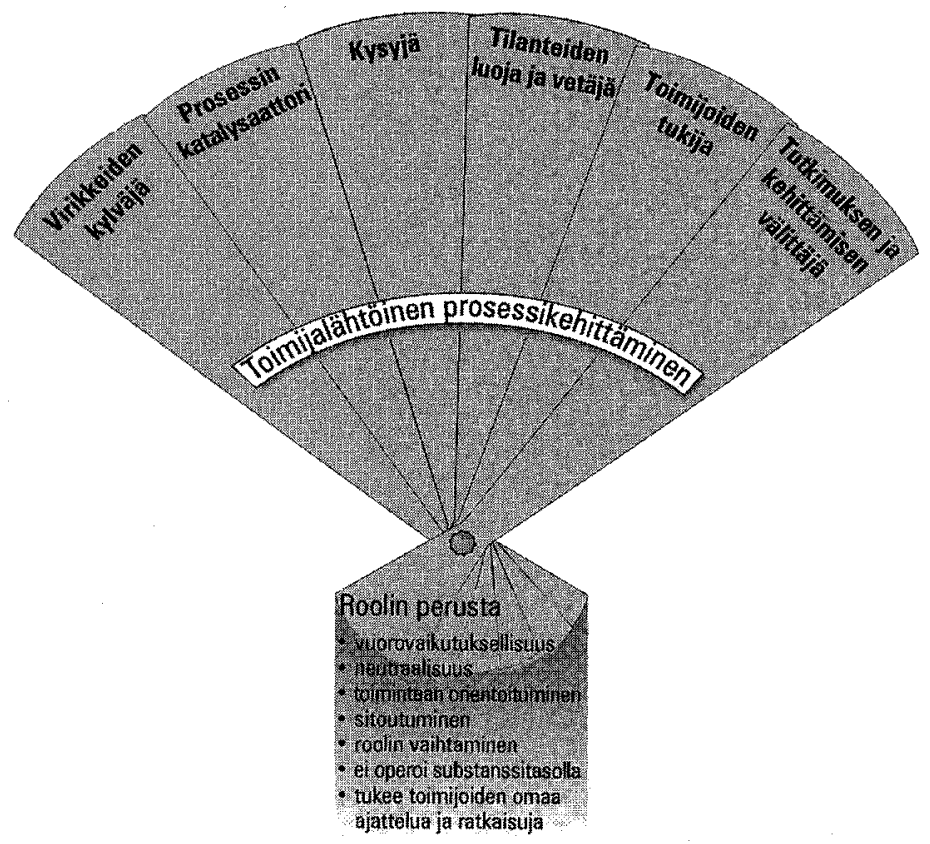

viittaa kykyyn toteuttaa tavoiteltavia asioita. (Kananoja 1981, 9.)

$\mathrm{T}$ oimijalähtöinen prosessikehittäjä ei vienyt valmiita ratkaisuja, eikä ottanut vastuuta kehitettävän substanssialueen sisällöstä, vaan piti lähinnä konsultatiivisesti työskentelevän etäisen suhteen kehitettävään alueeseen. Haastateltavat kertoivat paikoitellen tilanteista, joissa näkyi ristiriitaa heidän etäisemmän, konsultoivan työotteensa ja oman kehittämistehtävään voimakkaan sitoutumisensa välillä. Voimakas sitoutuminen veti kehittämistapahtumien etulinjaan aktiiviseksi osallistujaksi. Onkin sanottu, että todelliseen kehittämiseen kuuluu tämäntyyppinen etulinjan rooli ja siihen liittyvä vastuu (Buhanist \& Kosonen 1996, 21). Toisaalta voimakkaaseen sitoutumiseen voi sisältyä myös ylisitoutumisen vaara. Tällöin on riski, ettei pysty itse näkemään omaa toimintaansa suhteessa kontekstiin.

Kehittämistyössä näyttäytyvät usein erilaiset ja risteävät intressit (Meeuwisse 1993). Muutosja oppimisvaateet nostattavat esille myös ihmisten ristiriitaisia tunteita, jotka vahvistavat kehittämistilanteiden epävakaata luonnetta (ks. Ekholm 1994, 19). Haastateltavien mukaan hei- dän roolinaan oli kuitenkin olla neutraali välittäjähahmo. Tähän kuului tietty sitoutumattomuus, mikä oli erityisen tärkeätä projektikumppaneiden luottamuksen saavuttamisessa. Neutraalisuutta lähellä oleva asia oli puuttumattomuus toimijaorganisaatioiden sisällä oleviin ristiriitoihin.

Paikallisten toimijoiden kehittämistyötä aktivoiva, tukeva ja mahdollistava työtapa merkitsi kehittäjän profiloitumista valmentajan ja taustavaikuttajan asemaan. Tähän kuului kehittäjän toiminnan "näkymättömyys", jolla annettiin tilaa toimijoiden vahvistumiselle. Informanttien mukaan projektikumppaneita tuli tukea ja vahvistaa, innostaa ja motivoida. Haastateltavat kuvasivat rooliansa lähestulkoon samoin kuin Stakesin strategiapaperi (1997), jonka mukaan kehittämistyössä korostuu käytännön ammattilaisten rooli toimijoina ja Stakesin asema heidän kumppaninaan. Haastateltavat puhuivat prosessin katalysoimisesta. Siinä kehittäjä aktivoi ja viritti toimijakenttää kehittämistehtävän suuntaisesti, mutta pysyi itse kuitenkin sivussa. Prosessin käynnistämisessä ja kuljettamisessa kehittäjä toimi katalysaattorina tai kätilönä, kuten muutamat haastateltavat rooliansa kuvasivat. Kataly- 
saattorina hän oli ikään kuin välittäjäaine, joka rakensi, siirsi ja muotoili ihmisten väliseen vuorovaikutukseen perustuvia prosessin elementtejä. Kehittäjä toi toimijoita yhteen, loi tilanteita ja foorumeita, joissa kehittämispyrkimykset voivat lähteä realisoitumaan.

Käsitykseen, jonka mukaan kehittäjä ei vie valmiita vastauksia, vaan pyrki luomaan ratkaisuja synnyttäviä prosesseja, kuului kyselijän rooli. Kysymysorientoitunut vuorovaikutus on mielenkiintoinen myös siinä mielessä, että siinä tilannetta ohjataan haluttuun suuntaan hienovaraisesti. Asetelmassa vastaaja tai ratkaisun löytäjä on tavallaan aktiivinen subjekti. Eräs haastateltavista puhuikin "oikeiden kysymysten" tärkeydestä. Oikeilla kysymyksillä saadaan aikaan oivalluksia, sitoutumista ja prosessin eteneminen haluttuun suuntaan (myös Schein 1987, 122). Kysymysorientaatioilla kehittäjä ikään kuin häivyttää oman asiantuntijaroolinsa. Haastateltavien kuvauksissa oli kuitenkin havaittavissakin tietty imu neuvoa, kertoa ja ohjata. He joutuivat myös ponnistelemaan tätä imua vastaan.

$\mathrm{D}^{2}$ audelin tuo esille kysymysten tärkeyden refektoivassa toiminnassa, joka parhaimmillaan johtaa oppimiseen. Sinänsä kysymysten käyttämisellä on pitkät perinteet; opettajat, kouluttajat ja terapeutit ovat perinteisesti havainneet kysymysten voiman oppimisen ja löytämisen välineinä. Hän viittaa myös oikeiden ja toimivien kysymysten käyttämiseen, sillä erilaisilla kysymyksillä on erilainen vaikutus. Niillä avataan vaihtoehtoisia ja uusia ajatuksia ja näkymiä, selvennetään merkityksiä sekä jäsennetään tulevaa toimintaa. Kysymyksillä, kuuntelemisella ja neuvoilla tuetaan reflektion onnistumista. (Daudelin 1996.) Dialogisuus tekee mahdolliseksi reflektion ja sitä kautta oppimisen. Kysymysten tekeminen on olennainen osa tätä oppimisprosessia. Kysymykset ovat välttämätön väline päästä kiinni toiminnan syvempiin ulottuvuuksiin, kuten tavoitteisiin, intresseihin ja taustaoletuksiin. (Preskill \& Torres 1999.)

Kehittämisvirikkeet olivat usein tutkimuksen tuottamaa tietoa, ja haastateltavien mielestä kehittäjän rooli oli myös tutkimustiedon välit- täminen. Virikkeillä suunnattiin prosessia ja aktivoitiin toimijoita omaksumaan kehitettävä asia; voidaan siis puhua informaatiolla ohjaamisesta. Informaatio-ohjaaja kerää, jalostaa ja välittää tietoa sekä tukee toimijatasolla olevien vuorovaikutusta (Stakes 1999, 5). Kehittäjä, jolla oli tyypillisesti tutkijatausta, työskenteli tutkimuksen ja kehittämisen maailmoiden välittäjänä. Hän käytti tutkimusta ja tutkimuksellisia menetelmiä kehittämisen välineenä tavoitteiden saavuttamiseksi. Tutkimustuloksia välitettiin projektien käyttöön ja innostettiin toimijoita pienimuotoiseen tutkimustoimintaan.

Kehittäjän roolia ideoiden ja virikkeiden levittäjänä voitaisiin kutsua kuvainnollisesti "sanansaattajaksi" tai "ilosanoman levittäjäksi", kuten eräs haastateltava asian muotoili. Samantyyppinen rooli on valistaja, jota voidaan pitää perinteisenä asiantuntijatyyppinä. Valistukselta edellytetään, että se auttaa käsittelemään käsillä olevaa kysymystä. Hyvältä valistavalta asiantuntijalta odotetaan, että hän tuntee asiansa sekä sellaisia menetelmiä, joilla asiakkaat ymmärtävät sanoman (Pirttilä 1996, 75).

\section{Lopuksi}

Olen keskustellut artikkelissa kehittämistyön erityispiirteistä kehittäjäammattilaisten näkökulmasta, heidän käsityksistään työstään ja siihen liittyen kehittäjän roolin moninaisuudesta. Tarkastelu on perustunut tutkimukseni (Seppänen-Järvelä, 1999) empiirisen aineiston analyysiin.

K ehittäjien käsitykset roolistaan, paikastaan ja Yyöotteestaan liittyvät olennaisesti pohdintaan kehittämistyön olemuksesta. Onkin sanottu, että asiantuntijoilta vaaditaan nykyistä huomattavasti herkempää tietämystä omasta ekspertiisistään ja sen rajoista (Kasvio ym. 1999, 294). Perinteisten asiantuntija-asemien mureneminen ja uudenlaisen hahmon saaminen näyttäytyy kehittämisen kommunikatiivisuutta painottavissa lähestymistavoissa, kuten toimijalähtöisessä prosessikehittämisessä.

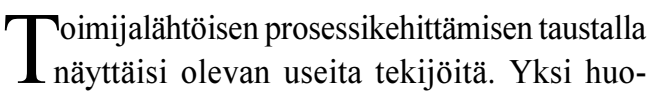


mattavimpia oli se, etteivät haastateltavien käsitykset olleet muodostuneet tyhjiössä (ks. myös Kasvio ym. 1999, 34). Samanpiirteisiä kehittämistyön ajattelutapoja on löydettävissä tutkimusorganisaation ja sosiaali- ja terveydenhuollon alueen ulkopuoleltakin. Kysymyksessä ovat siis ajattelutapojen aikalaisvirtaukset ja universaalit trendit, jotka sisäistetään osaksi omaa ajattelua. Kehittämisajattelut ovat sidoksissa laajempaan yhteiskunnalliseen viitekehykseen, ideologiseen ajatusrakennelmaan tai tieteelliseen traditioon. Näin eri aikoina esitetyistä kehittämiskäsityksistä heijastuvat aikalaisajattelun piirteet. Trendin omaksuminen voi olla organisaatiolle myös imagotekijä. Viestittämällä muille - käyttämällä oikeita käsitteitä - organisaatio varmistaa paikkaansa toimintaympäristössään.

$\mathrm{H}^{2}$ aastateltavien käsityksistä muodostuvaa kuvaa voitaisiin kritisoida epärealistisen ristiriidattomaksi. On kuitenkin havaittava, että potentiaalinen tekijä, joka saattoi vaikuttaa aineistossa ilmenneeseen kehittäjien puheen retoriseen sävyyn, oli itse puheaineiston luonne. Tutkimusasetelma, haastattelutilanne ja muut kontekstuaaliset - lähinnä tutkimusorganisaation sisäiset - tekijät vaikuttivat siihen, että haastateltavien puhe oli luonteeltaan kehittämistyön legitimaatiopuhetta. Tällöin siihen saattoi sisältyä myös verrattain ideaaleja piirteitä. Voidaankin ajatella, että haastateltavien puheet ilmentävät Argyriksen ajattelutapaa julki- ja käyttöteorioista. Aineisto olisi tällöin lähinnä julkiteorian luonteista; siinä luodaan jaettuja merkityksiä, joiden avulla on mahdollista selvittää ja kuvailla toimintaa ja tapahtumia. Niiden avulla on mahdollista kuvata ulkopuolisille, mistä kehittämistyössä on kysymys. (Argyris 1994.)

$\mathrm{V}$ aikka haastateltavien käsitykset olivat suhteellisen positiivisesti värittyneitä, tuli niissä selvästi esille tiettyjä kehittämistyöhön liittyviä jännitteitä, jotka usein kytkeytyvät kehittäjän positioon ja rooleihin. Eräs keskeinen näistä on toimijalähtöisen prosessikehittämisen luonteeseen kuuluva tasapainoilu prosessin mahdollistajan tai "kätilön" ja toisaalta ratkaisuja antavan ekspertin välillä. Tämä liittyy siihen, kuinka syvälle prosessiin ja millaisella otteella kehittäjä osallistuu.
Tämäntyyppisen roolidilemman havaitsee myös Kuula (2000) toimintatutkijoiden työssä. Toisaalta voidaan sanoa, että aineiston valossa jää moni tärkeä asia keskustelun ulkopuolelle. Tällaisia ovat esimerkiksi kysymykset asiantuntijaasemaan liittyvästä vallankäytöstä. Organisaatioilla tai ammattikunnilla on institutionaalista valtaa, jota niiden edustajat työssään kantavat. Vaikka kysymys kehittämistyön roolista poliittis-hallinnollisena ohjauskeinona jää epäselväksi, herättää se silti kysymään, millainen väline kehittämistyö on institutionaalisen vallankäytön ja ohjauksen kannalta.

\section{Lähdeluettelo}

AHONEN, PERTTI (1997). Crisis of the administrative welfare state \& Evaluation of current reforms of the administrative welfare state. In: Ahonen \& Salminen (eds.) Metamorphosis of the administrative welfare state. Scandinavian University Studies 14. Frankfurt am Main: Peter Lang.

ALBÆK, ERIK (1995). Reforming the Nordic welfare communes. International review of administrative sciences 2, 241-264

ARGYRIS, CHRIS (1993). Knowledge for action. A guide to overcoming barriers to organizational change. San Francisco: Jossey-Bass Publishers

ATLAS/TI (1999). http://www.atlasti.de. Tulostettu 4.2.1999

BUHANIST, PAUL \& Kosonen, K (1996). Asiakasohjautuva toimintatutkimus. Työelämän tutkimus 1 , $18-20$

BUHANIST, PAUL \& Kasvio, Antti \& Kauppinen, Timo \& Lahtonen, Maarit (1994). Finnish action research. Action research in Finland. Labour policy studies 82. Helsinki: Ministry of Labour.

BRÄNNBERG, TORE (1996). Eldsjälar och projektmakare. I: Sahlin (red.) Projektets paradokser. Lund: Studentlitteratur.

CASTELLS, MANUEL (1996). The rise of the network society. Oxford: Blackwell Publishers.

DAUDELIN, MARILYN (1996). Learning from experience through reflection. Organizational Dynamics 3, 13-36

EKHOLM, MATS (1994). Fösäkringskassan i utveckling. En granskning av ett decenniums utvecklingsprojekt. Stockholm: Rikförsäkringsverket.

ERÄSAARI, RISTO (1996). Mistä asiantuntijuus on kotoisin? Teoksessa: Kirjonen \& Remes \& Eteläpelto (toim.) Munttuva asiantuntijuus. Koulutuksen tutkimuslaitos. Jyväskylä: Jyväskylän yliopisto.

FILANDER, KARIN (1995). Muutosagentit epävarmuuden ajassa - puhetta, toimintaa, oppimista. Kasvatustieteiden laitoksen lisensiaatintutkimus. Tampere: Tampereen yliopisto.

GUSTAVSEN, BJÖRN (1992). Dialogue and development. Social science for social action: toward organizational renewal. Assen: Van Gorcum \& comp. 
HONKANEN, HENRY (1999). Organisaation kehittämismallien juurista tulevaisuuden haasteisiin. $A i$ kuiskasvatus 1, 16-22.

JALAVA, URPO \& Virtanen, Petri (1998). Tietoa luova projekti. Polku oppivaan organisaatioon. Helsinki: Kirjayhtymä

KANANOJA, AULIKKI (1981). Ihminen kehittäjänä kehittäjä ihmisenä. Piirteitä Beatrice Webbin kehittäjän kuvasta. Teoksessa: Käytäntö ja kehittäminen. Veikko Niemen juhlakirja. Helsinki: Sosiaalityöntekijäin Liitto, Invalidiliitto, Invalidisäätiö, Keuhkovammaliitto, Kuntoutussäätiö, Sosiaalihuoltajat, Sosiaaliturvan Keskusliitto, Vakuutusalan Kuntouttamiskeskus.

KASVIO, ANTTI (1994). Työelämän muutos ja toimintatutkimus. Sosiologia 1, 24-34.

KASVIO, ANTTI \& Lahtonen, Maarit \& Varis, Maarit \& Airaksinen, Jenni (1999). Kehittäminen arjen voimavaraksi. Tutkimus toimintatapojen kehittämisestä Helsingin kaupungin työpaikoilla vuosina 1995-1998. Tampere: Tampereen yliopisto.

KESKI-PETÄJÄ, TIMO (1999). Vapaa sivistystyö kolmannen sektorin oppimisfoorumina. Case KYP esimerkkinä projektityön koulutuksesta. OK-opintokeskuksen julkaisuja (painossa).

KUULA, ARJA (2000). Toimintatutkimus. Kenttätyötä ja muutospyrkimyksiä. Tampere: Vastapaino

LINDSTRÖM, KARI (1997). Tutkimus työelämän kehittämisen tukena. Teoksessa: Alasoini \& Kyllönen \& Kasvio (toim.) Työelämän innovaatiot - väline kilpailukyvyn, hyvinvoinnin ja työllisyyden edistämiseen. Kansallisen työelämän kehittämisohjelma. Raportteja 2. Helsinki: Työministeriö.

MARTON, FERENCE (1988). Phenomenography - a research approach to investigate different understanding of reality. In: Sherman \& Webb (eds.) Qualitative research in education: focus and methods. London: Falmer Press.

MEEUWISSE, ANNA (1996). Projektens dolda funktioner. I: Sahlin (red.) Projektets paradokser. Lund: Studentlitteratur

NASCHOLD, FRIEDER (1995). The modernization of the public sector in Europe. A comparative perspective on the Scandinavian experience. Labour policy studies 93. Helsinki: Ministry of Labour.

OAKLEY, PETER (1990). The evaluation of social development. In: Marsden \& Oakley (eds.) Evaluating social development projects. Development guidelines 5. Oxford: Oxfam.

PATTON, MICHAEL (1997). Utilization-focused evaluation. The new century text. Thousand Oaks: Sage Publications

PIRTTILÄ, ILKKA (1996). Teoria, markkina-analyysi ja futurologinen silmä eksperttiyden ehtoina. Teoksessa: Kirjonen \& Remes \& Eteläpelto (toim.) Muuttuva asiantuntijuus. Koulutuksen tutkimuslaitos. Jyväskylä: Jyväskylän yliopisto.

PRESKILL, HALLIE \& Torres, Rosalie (1999). Building capacity for organizational learning through evaluative inquiry. Evaluation 1, 42-60

RAJAVAARA, MARKETTA (1994). Kaikenlaisia kehittäjiä ja kehittämisajatteluja. Teoksessa: Lindqvist \& Rajavaara (toim.) Kehittämistyö itseanalyysiin. Helsingin yliopiston Lahden tutkimus- ja koulutuskeskuksen julkaisuja 8 ja Stakesin raportteja 147. Helsinki: Helsingin yliopisto ja Stakes.
RAUSTE-VON WRIGHT, MAIJALIISA \& von Wright, Johan (1996). Oppiminen ja koulutus. Juva: WSOY.

SAARI, JUHO (1998). Sosiaalipoliittinen innovaatiotutkimus. Teoksessa: Niemelä \& Saari \& Salminen (toim.) Innovatiivinen sosiaalipolitiikka. Sosiaali- ja terveysturvan katsauksia 25. Helsinki: Kansaneläkelaitos.

SCHEIN, EDGAR (1969). Process consultation: it's role in organization development. Volume I. Reading: Addison-Wesley Publishing Company.

SCHEIN, EDGAR (1987). Process consultation. Lessons for managers and consultants. Volume II. Reading: Addison-Wesley Publishing Company.

SCHEIN, EDGAR (1999). Process consultation revisited. Building the helping relationship. Reading: Addison-Wesley Publishing Company.

SEPPÄNEN-JÄRVELÄ, RIITTA (1999). Luottamus prosessiin. Kehittämistyön luonne sosiaali- ja terveysalalla. Tutkimuksia 104. Stakes.

STAKES UUDELLE VUOSITUHANNELLE. Stakesin strategia (1997). Helsinki: Stakes

STAKES (1999). Vuosikertomus 1998. Helsinki: Stakes.

STRAUSS, ANSELM \& Corbin, Juliet (1990). Basics of qualitative research. Grounded theory procedures and techniques. Newbury Park: Sage Publications.

TEMMES, MARKKU (1998). Finland and New Public Management. International Review of Administrative Sciences 9, 441-456.

UUSITALO, HANNU \& Lönnfors, Terhi (1999). Sosiaalija terveydenhuollon ohjaus. Teoksessa: Uusitalo (toim.) Stakes sosiaali- ja terveysalan informaatio-ohjaajana. Kokemuksia ja kehitysnäkymiä. Aiheita 11. Helsinki: Stakes

VALKEAVAARA, TUIJA (1997). HRD practitioners analysing their work: what does it tell about their present role in working life? Social change and adult education research. Adult education research in Nordic Countries 1996. Institute for educational research. Jyväskylä: University of Jyväskylä.

Artikkeli saapui toimitukseen 12.11.1999. Se hyväksyttiin julkaistavaksi 31.1.2000. 